\title{
Relationship between Remittance and Economic Growth: Evidence from Bangladesh
}

Md. Sujahangir Kabir Sarkar ${ }^{*}$, Md. Zillur Rahman², Mohammad Muzahidul Islam³ ${ }^{3}$ Md. Mehedi Hasan Sikdar $^{4}$, Abul Basher Khan ${ }^{5}$

${ }^{1,5}$ Associate Professor, Department of Economics and Sociology, Patuakhali Science and Technology University, Patuakhali, BANGLADESH

${ }^{2}$ Associate Professor, Department of Language and Communication, Patuakhali Science and Technology University, Patuakhali, BANGLADESH

${ }^{3}$ Associate Professor, Department of Management Studies, Patuakhali Science and Technology University, Patuakhali, BANGLADESH

${ }^{4}$ Associate Professor, Department of Statistics, Patuakhali Science and Technology University, Patuakhali, BANGLADESH

*E-mail for correspondence: skabirbau2000@gmail.com

\begin{abstract}
Remittance is one of the major sources of capital especially for the developing countries like Bangladesh. This study attempts to explore the relationship between remittance and economic growth in Bangladesh. Time series data from 1995-2016 extracted from the World Bank database as well as Bangladesh Bank statistics were used to measure the relationship of remittance and gross domestic product (GDP) with some other variables such as gross capital formation, gross domestic saving and household final consumption expenditure. Pearson's correlation coefficient is estimated between the variables. Moreover, annual growth (\%) of remittance earning by Bangladesh has been calculated and compared with the GDP growth of Bangladesh. The study has found that on an average, remittance of Bangladesh has been increased by 10.85\% from 1995-2016 which is higher than the average growth of the country's GDP. It has revealed that there is a positive relationship of remittance with the GDP, gross capital formation, domestic saving and household final consumption expenditure in case of Bangladesh. However, there is a frequent fluctuation of remittance flow in Bangladesh in the recent years. Thus, this study recommends that Bangladesh should take proper initiatives for maintaining an increasing trend of remittance in the coming years which would be useful for the socio-economic development of the country.
\end{abstract}

Keywords: Remittance, Economic Growth, Bangladesh

\section{INTRODUCTION}

Bangladesh is a lower middle-income country located in South Asia. In spite of several problems including political instability, corruption, lack of good governance, the country is advancing over time. Bangladesh is one of the most densely populated countries in the world. However, the population can be blessings if it can transform them into the human resource. The country's population has been increased from 119 million in 1995 to 160 million in 2016 while the total labor forces have been risen to 72 million in 2016 from 52 million in 1995 (World Bank, 2017a). Figure 1 presents the increasing trend of population and labor force of Bangladesh.

This large volume of workforce needs to be engaged in employment to ensure their participation in the economic development of the country as well to improve their standard of living. Bangladesh has a huge potential of its labor force especially the surplus manpower combining with professional, skilled, semi-skilled and less-skilled labor force (Islam, 2011). Migration of a large number of labor force results higher remittance inflows in the country. It can be mentioned that inflow of remittance is increasing over the year in Bangladesh which plays an important role in the development of the migrant families and the countries as well. Remittance has become a crucial aspect for the developing countries like Bangladesh for socioeconomic advancement. It has a significant role to maintain a favorable balance of payment and to enrich foreign currency reserve and also has a great contribution to Gross Domestic Product (GDP) of the country (Islam, 2011). The remittances flow in Bangladesh has grown not only in size but also in importance regarding the share of gross domestic product (GDP). Remittances represent the 
second largest source of foreign currency earnings after exports, which have contributed above 10 percent of GDP (Chowdhury, 2012). Hasan (2006) shows that remittance has a significant macroeconomic impact at the household level, the more impact or benefit of remittance income can have to alleviate poverty. Jongwanich (2007) finds that remittances have a positive but marginal impact on economic growth in Asia and Pacific countries. Therefore, it is important to determine the effect of remittance on the household and the economy. Thus, this study attempts to explore the relationship between remittance and economic growth in case of Bangladesh.

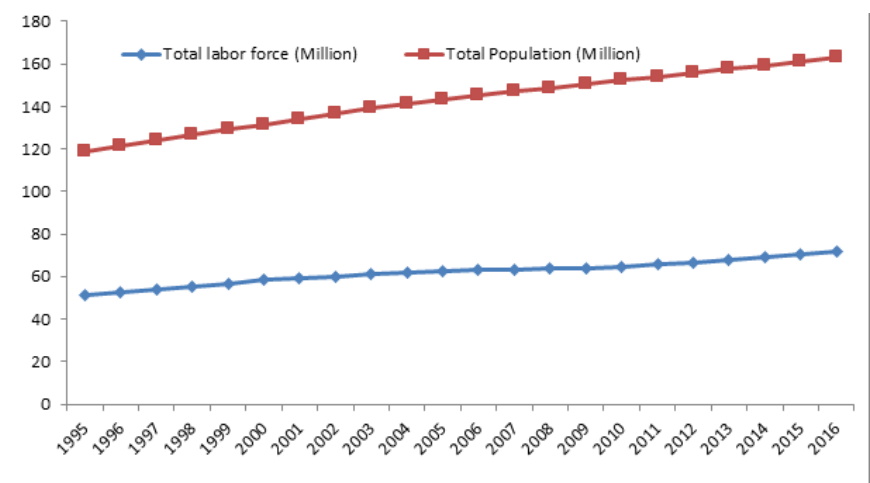

Figure 1: Total population and labor force in Bangladesh from 1995-2016

\section{Methodology}

This study explores the relationship between remittance and economic growth of Bangladesh by using the time series data from 1995-2016 which have been collected from the World Development Indicators of the World Bank database as well as Bangladesh Bank statistics. It has also derived trends of some variables including remittance earnings and gross domestic product (GDP) along with their comparison based on the data from 1995 to 2016. The study calculates annual growth (\%) of remittance earning by Bangladesh based on the equation one which is compared with the GDP growth of Bangladesh.

Annual growth of Remittance $=$

$\left(\frac{\text { current year remittance-previous year remittance }}{\text { Previous year remittance }}\right) \times 100 \ldots \ldots$

It is mentioned that remittance is one of the most important economic indicators for Bangladesh as it helps in balancing balance of payments, increasing foreign exchange reserves, enhancing national savings and increasing velocity of money by increasing (Ali, 2014). Therefore, for exploring the relationship remittance and economic growth, this study has been measured the relationship of remittance and gross domestic product (GDP) with some other variables such as gross capital formation, gross domestic saving and household final consumption expenditure. However, this study has used Pearson's correlation coefficient to explore the relationship between remittance and GDP using the following formula.
$r=\frac{\sum_{i=1}^{n}\left(X_{i}-\bar{X}\right)\left(Y_{i}-\bar{Y}\right)}{\sqrt{\sum_{i=1}^{n}\left(X_{i}-\bar{X}\right)^{2}} \sqrt{\sum_{i=1}^{n}\left(Y_{i}-\bar{Y}\right)^{2}}} \ldots \ldots \ldots \ldots$

Where $\mathrm{r}=$ Pearson's correlation coefficient; $X=$ remittance earnings, $\mathrm{Y}=\mathrm{GDP} ; \bar{X}=$ mean of $\mathrm{X} ; \bar{Y}=$ mean of $\mathrm{Y} ; \mathrm{i}=$ number of years. The value of correlation coefficient ranges between -1 (total negative correlation) and +1 (total positive correlation). The similar technique has been used to measure the relationship between remittance and gross capital formation, remittance and gross domestic saving and remittance and household final consumption expenditure.

\section{REsults AND Discussion}

\section{Remittance and its growth in Bangladesh}

Bangladesh is one of the largest remittance recipient countries through the export of its labor forces mainly to the Middle East and the Southeast Asian countries since the early 1970s. Bangladeshi workers are now working in a large number of countries including Saudi Arabia, UAE, Qatar, Kuwait, Oman, Malaysia, USA, UK, Italy and South Africa and so on. Job in Middle-east is one of the major sources of remittance inflow for Bangladesh as it has provided great scope for Bangladeshi workers for employment. Globalization has also played important role in the rise of demand for migrant workers globally. This external demand opened up scope for a large number of Bangladeshis (mostly semi-skilled and less skilled) to go abroad as migrant workers (ILO, 2014). Bangladesh is a country of surplus manpower resources with a combination of the professional, skilled, semi-skilled and less-skilled labor force. Almost two million young people are added to the labor force every year (BBS, 2013). But the country cannot create jobs to absorb them. As a result, the outflow of Bangladeshi workers will continue in the foreseeable future.

According to World Bank Estimates of 2013, Bangladesh is the 5th top emigration country with 7.76 million. Up to 2015 May, Bangladesh has sent more than 9.34 million workers to 142 countries (BMET, 2015 and BBS, 2013). Due to this mass movement of temporary migrant workers, the remittance transfers received from these migrant workers have reached a level of 15.31 billion US dollars in 20142015, approximately $7.9 \%$ of GDP in Bangladesh which was 14.23 billion US dollars in the year 2013-2014 (Bangladesh Bank, 2015). From 1976-2014, annual migration from Bangladesh is about 0.2-0.3 million, i.e. every year about 200,000 or more Bangladeshis leave the country to work overseas (BMET, 2015). Most of these migrants send part of their earnings home regularly or irregular basis. Bangladesh receives 2.6 percent of global remittance flow. This share was 3.5 percent among developing countries and accounted for 12.8 percent of the official remittances flowing into South Asia in 2014. The country ranked the 8 th among developing countries and 10th globally as a remittance receiving country in 2013 with 
a remittance earning of US\$13.86 billion. Bangladesh has been maintaining position within top 10 remittance recipient countries since last 15 years from 2004 to 2014 . The size of the global remittance market was over $\$ 601$ billion in 2015 (World Bank, 2017b). Table 1 shows the top 10 remittance receiving countries in 2015 based on World Bank data.

Table 1: Top remittance receiving countries in the world in 2016

\begin{tabular}{|l|l|l|}
\hline & $\begin{array}{l}\text { Total Remittance Earnings } \\
\text { (Billion US\$) }\end{array}$ & Rank \\
\hline India & 62.7 & 1 \\
\hline China & 61.0 & 2 \\
\hline Philippines & 29.9 & 3 \\
\hline Mexico & 28.5 & 4 \\
\hline Pakistan & 19.8 & 5 \\
\hline Nigeria & 19.0 & 6 \\
\hline Egypt & 16.6 & 7 \\
\hline Bangladesh & 13.7 & 8 \\
\hline Vietnam & 13.4 & 9 \\
\hline Indonesia & 9.2 & 10 \\
\hline
\end{tabular}

Source: World Bank, 2017b

Bangladesh has already become one of the top 10 remittance-recipient countries in the world which has strengthened the country's foreign exchange reserve. In 2016, Bangladesh has achieved the eighth position among the top 10 countries list after India, China, Philippines, Mexico, Pakistan, Nigeria and Egypt (World Bank, 2017a). This study has found that Bangladesh has earned US\$ 1198 million remittance in 1995 which has increased about 13 times as of US\$ 15317 million in 2015 (World Bank, 2017a). On an average, remittance has increased by $10.85 \%$ from 1995-2016. However, it is revealed that remittance of Bangladesh has fluctuated in recent years. As for example, the amount of remittance has decreased from US\$ 15317 million in 2015 to US\$ 14931 million in 2016 that indicates instability of remittance earning of Bangladesh. Thus, there is need special attention to maintain an increasing flow of remittance in Bangladesh from different countries.

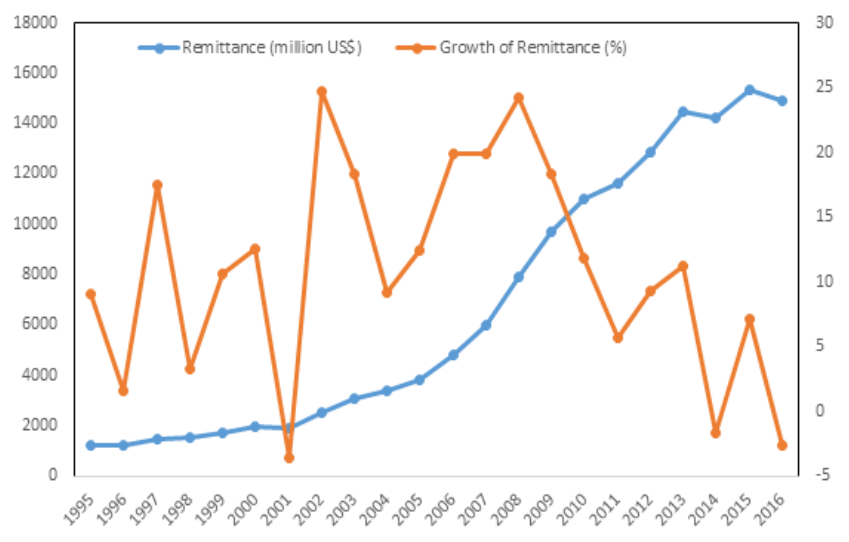

Figure 2: Remittance and its growth in Bangladesh from 1995-2016

\section{Trend of GDP and GDP Growth}

Bangladesh is a country which has maintained about $6 \%$ growth from past twenty years. This country has recently entered into the lower middle-income country from lowincome country. The country's economy is growing over the years. It has found that the GDP (gross domestic product) of Bangladesh was US\$ 52934 million in 1995 which was increased by more than three times in 22 years at US\$ 167771 million in 2016. Figure 3 provides the trend of GDP and its yearly growth. It is revealed that Bangladesh has maintained an increasing trend of its GDP over the year while GDP growth has fluctuated. However, the average GDP growth of Bangladesh has estimated as $5.63 \%$ from 1995-2016. In spite of some major problems such as political instability, high rate of corruption, insufficient foreign direct investment etc., Bangladesh economy is growing where contribution of remittance and private sector growth are remarkable. It is highlighted that Bangladesh economy has achieved a record growth by $7.28 \%$ in 2017 which is higher than the GDP growth in 2016 as of $7.11 \%$ (Bangladesh Bank, 2017).

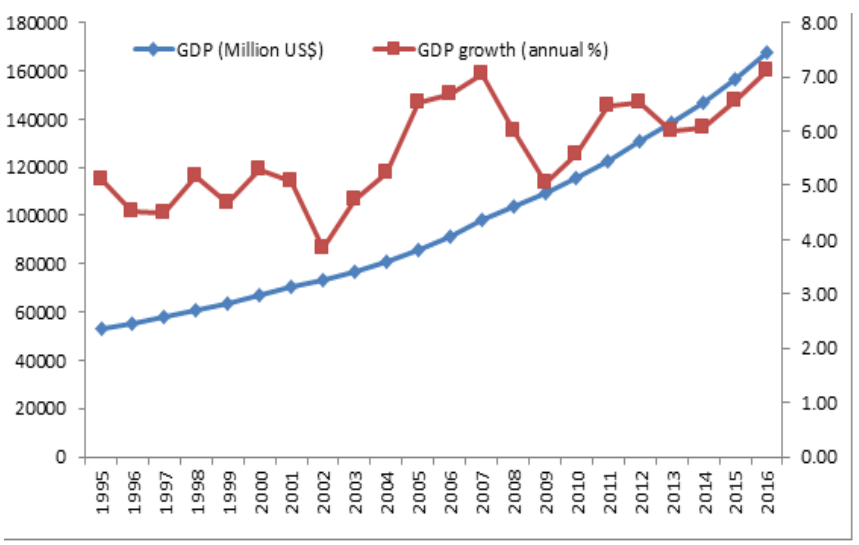

Figure 3: GDP and its growth (\%) in Bangladesh from 19952016

\section{Relationship between remittance and other selected variables}

Remittance can influence in an economy by many ways. Some studies identify the effect of remittance on macroeconomic aspect. Rao and Hassan (2012) attempted to analyze the direct growth effects of remittances on the economy. They have shown that remittances indirectly facilitate economic growth by increasing the ratio of Broad Money (M2) to GDP. Siddique et al. (2010) conducted a study on remittance and economic growth on major South Asian countries (i.e., Bangladesh, India and Sri Lanka). Their empirical analysis identifies that remittances have a mixed response with the economic growth. The study finds no causal relationship between remittance and economic growth in the case of Bangladesh and India. But for Sri Lanka, a two-way causal relationship has found between remittance and economic growth. Another study finds that though there exist a long-run relationship between the remittance and economic growth but there does not have 
long-run causal relation between the two variables (Datta and Sarkar, 2014). Das and Chowdhury (2011) investigated long run relationship between remittances and GDP of 11 top remittance-recipient developing countries including Bangladesh. They applied latest developed econometric techniques, i.e., panel co- integration and pooled mean group (PMG) approach. The results support a positive long run relationship between remittances and GDP. However, the magnitude of the remittance-GDP coefficient is quite small. Their result also implies that developing countries should formulate policies to divert this external resource into more productive sectors.

This study has estimated the relationship between remittance and some other variables related to economic growth (Table 3 in the Appendix presents the data for all of the variables). Remittance can influence a developing country's economy by changing household income and expenditure, domestic saving and investment and so on. This study has found that there is a significant positive correlation between the remittance and GDP in Bangladesh based on the data from 1995-2016.). Moreover, the results also show that remittance is also significantly correlated with the gross capital formation, gross domestic saving and household final consumption expenditure which is shown in Table 2. The result shows that the correlation coefficient between GDP and remittance is found as $0.981^{* *}$ which indicates that GDP is positively and significantly correlated with the remittance. It is also revealed that gross capital formation, gross saving and household final consumption expenditure are positively correlated with remittance as well as GDP. Therefore, it is said different macroeconomic variables such as gross capital formation and gross saving are influenced by the remittance which ultimately influence the GDP or economic growth of Bangladesh. Figure 4 also provides the flow of remittance and GDP of Bangladesh from 1995-2016. The linear trend lines for both remittance and GDP support the positive relationship between remittance and GDP of Bangladesh.

Table 2: Relationship between remittance and other selected variables

\begin{tabular}{|c|c|c|c|c|c|c|}
\hline & \multicolumn{5}{|c|}{ Correlations } \\
\hline & & $\begin{array}{c}\text { Remit } \\
\text { tance }\end{array}$ & GDP & $\begin{array}{c}\text { Gross } \\
\text { capital } \\
\text { formation }\end{array}$ & $\begin{array}{c}\text { Gross } \\
\text { domestic } \\
\text { saving }\end{array}$ & $\begin{array}{l}\text { Household } \\
\text { final } \\
\text { consumption } \\
\text { expenditure }\end{array}$ \\
\hline Remittance & $\begin{array}{l}\text { Pearson Correlation } \\
\text { Sig. (2-tailed) } \\
\text { N }\end{array}$ & \begin{tabular}{|c|}
1 \\
22 \\
\end{tabular} & $\begin{array}{c}.981^{* *} \\
.000 \\
22\end{array}$ & \begin{tabular}{|c|}
$.952^{* *}$ \\
.000 \\
22
\end{tabular} & \begin{tabular}{c|}
$.926^{* *}$ \\
.000 \\
22
\end{tabular} & $\begin{array}{c}.966^{* *} \\
.000 \\
22\end{array}$ \\
\hline GDP & $\begin{array}{l}\text { Pearson Correlation } \\
\text { Sig. (2-tailed) } \\
\text { N }\end{array}$ & $\begin{array}{c}.981^{* *} \\
.000 \\
22\end{array}$ & $\begin{array}{l}1 \\
22\end{array}$ & $\begin{array}{l}.980^{* *} \\
.000 \\
22\end{array}$ & $\begin{array}{l}.967^{* *} \\
.000 \\
22\end{array}$ & $\begin{array}{l}.982^{* *} \\
.000 \\
22\end{array}$ \\
\hline $\begin{array}{l}\text { Gross capital } \\
\text { formation }\end{array}$ & $\begin{array}{l}\text { Pearson Correlation } \\
\text { Sig. (2-tailed) } \\
\text { N }\end{array}$ & $\begin{array}{c}.952^{* *} \\
.000 \\
22 \\
\end{array}$ & $\begin{array}{c}.980^{* *} \\
.000 \\
22\end{array}$ & $\begin{array}{c}1 \\
22 \\
\end{array}$ & $\begin{array}{l}.995^{* *} \\
.000 \\
22\end{array}$ & $\begin{array}{c}.997^{* *} \\
.000 \\
22\end{array}$ \\
\hline $\begin{array}{c}\text { Gross domestid } \\
\text { saving }\end{array}$ & $\begin{array}{l}\text { Pearson Correlation } \\
\text { Sig. (2-tailed) } \\
\text { N }\end{array}$ & $\begin{array}{c}.926^{* *} \\
.000 \\
22 \\
\end{array}$ & $\begin{array}{c}.967^{* *} \\
.000 \\
22\end{array}$ & $\begin{array}{c}.995^{* *} \\
.000 \\
22 \\
\end{array}$ & $\begin{array}{l}1 \\
22 \\
\end{array}$ & $\begin{array}{c}.987^{* *} \\
.000 \\
22\end{array}$ \\
\hline $\begin{array}{l}\text { household fina } \\
\text { consumption } \\
\text { expenditure }\end{array}$ & $\begin{array}{l}\text { Pearson Correlation } \\
\text { Sig. (2-tailed) } \\
\text { N }\end{array}$ & \begin{tabular}{c|}
$966^{* *}$ \\
.000 \\
22 \\
\end{tabular} & $\begin{array}{c}.982^{* *} \\
.000 \\
22 \\
\end{array}$ & $\begin{array}{l}.997^{* *} \\
.000 \\
22 \\
\end{array}$ & $\begin{array}{l}.987^{* *} \\
.000 \\
22\end{array}$ & 1 \\
\hline
\end{tabular}

** Correlation is significant at 0.01 level (2 tailed)

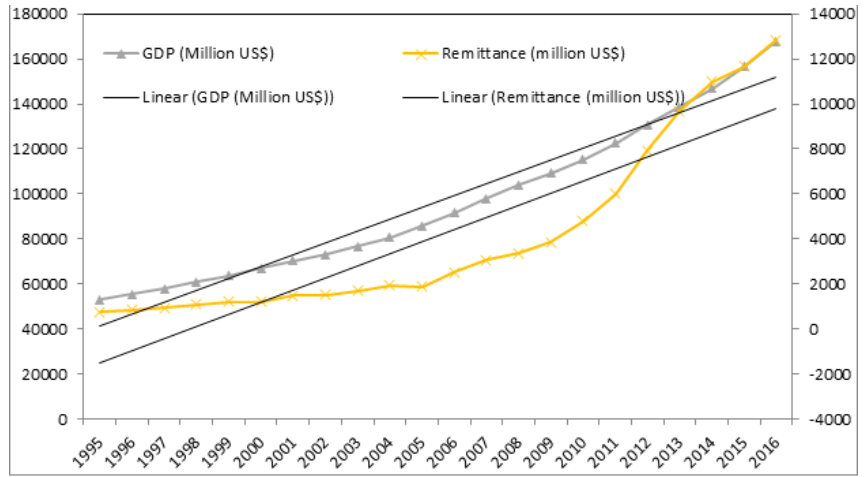

Figure 4: GDP and remittance of Bangladesh with their linear trend lines

\section{CONCLUSION AND POLICY IMPLICATIONS}

Remittance plays a vital role in the national economy through increasing household income, gross domestic saving, investment and ultimately economic growth. It has an immense potential for the socio-economic development of the remittance recipient countries. The steady growth of emigration from Bangladesh over the years is favorable to the development of Bangladesh; as the inflow of remittance has increased in the past years. The links between economic growth and remittance are obvious for a country like Bangladesh. However, recently, remittance flow has decreased in 2014 and 2016 compared to 2013 and 2015 respectively. Remittance flow is affected by different factors such as reduction of manpower export, high rate of emigrant to home countries, poor bilateral relationship with the manpower importing countries, lack of proper policy related to manpower export and so on. Good reputation of workers are also important for attracting more workers by the manpower importing countries. Therefore, this study suggests the following policy recommendation for increasing remittance flow in Bangladesh:

- Bangladesh should formulate proper manpower export policy for achieving higher remittance from the different countries

- $\quad$ The country has to build strong bilateral relationship with the remittance sending countries.

- Bangladesh needs to increase its bargaining power with the manpower importing countries for increasing the benefits of the workers which ultimately increase the remittance income.

- There is need to promote sufficient training and awareness programs for the workers that enhance skill of the workers and motivate them as well.

\section{REFERENCES}

Ali, M.A. (2014), "Socio-Economic Impact of Foreign Remittance in Bangladesh" Global Journal of Management and Business Research: C Finance, 14 (5):44-53.

Bangladesh Bank (2017), "Yearly data of Wage Earner's Remittance" Available at https:/ / www.bb.org.bd/econdata/wageremitance.php?txt Period=1\# (accessed 18 December 2017).

Bangladesh Bank, (2015), Various Issues, the Central Bank of Bangladesh, Government of the People's Republic of 
Bangladesh, Dhaka. Available at http://www.bangladeshBank.org/econdata/Wageremittance

BBS, (2013), "Report on Survey on the Use of Remittance 2013", BBS (Bangladesh Bureau of Statistics), Ministry of Planning. Available at http://www.bbs.gov.bd/WebTestApplication//userfiles/I mage/LatestReports/SUR_2013.pdf.

BMET, (2015), "Statistical Reports", BMET (Bureau of Manpower, Employment, and Training). Ministry of Expatriates Welfare and Overseas Employment Government of the People's Republic of Bangladesh. Available at http:/ / www.bmet.gov.bd/BMET/StatisticalDataAction.

Chowdhury, M.A. (2012), Migrant Workers and Remittances in Bangladesh Economy. Nagasaki University of Foreign Studies, (16):169-190.

Das, A. and M. Chowdhury (2011), "Remittances and GDP Dynamics in 11 Developing Countries: Evidence from Panel Cointegration and PMG Techniques", the Romanian Economic Journal, Year XIV, No. 42 December 2011.

Datta, K. and Sarkar, B. (2014), "Remittances and Economic Growth in Bangladesh: An ARDL Cointegration Approach", International Journal of Economic Issues, 7(1):51-65.

Hasan, R.A. (2006), "Harnessing Remittances for Economic Development of Bangladesh", Presented at INAFI Asia International Conference on Migration and Development,
Date: 23-27 May, Development Academy of the Philippines, Tagaytay City, Philippines.

Islam, M.N. (2011), "Bangladesh Expatriate Workers and their Contribution to National Development", Bureau of Manpower Employment and Training, Dhaka. Available at http:/ /www.bmet.gov.bd/BMET/resources/Static\%20PDF $\% 20$ and $\% 20$ DOC/publication/Remittance $\% 20$ and $\% 20$ its $\% 2$ 0impact.pdf

Jongwanich, J. (2007), “Workers' Remittances, Economic Growth and Poverty in Developing Asia and the Pacific Countries", UNESCAP Working Paper, WP/07/01.

Ratha, D., Eigen-Zucchi, C. and Plaza, S. (2016). Migration and Remittances Factbook 2016. World Bank Publications.

Siddique, A., E. A. Selvanathan and S. Selvanathan (2010), "Remittances and Economic Growth: Empirical Evidence from Bangladesh, India and Sri Lanka", the University of Western Australia, August, Discussion Paper, 10.27.

World Bank, (2017a), "World Development Indicators" Available at http:/ / databank.worldbank.org/data/reports.aspx?source=wo rld-development-indicators\# (Access on 17 November 2017).

World Bank. (2017b), "Migration and Development Brief 27. Migration and Remittances: Recent Developments and Outlook", World Bank, Washington, DC. Available at http:/ / pubdocs.worldbank.org/en/992371492706371662/ MigrationandDevelopmentBrief27.pdf

\section{APPENDIX}

Table 3: Remittance and some macroeconomic variables of Bangladesh from 1995-2016

\begin{tabular}{|c|c|c|c|c|c|c|c|}
\hline Year & $\begin{array}{c}\text { Total } \\
\text { Population } \\
\text { (Million) }\end{array}$ & $\begin{array}{l}\text { Total labor } \\
\text { Force } \\
\text { (Million) }\end{array}$ & $\begin{array}{c}\text { Remittance } \\
\text { (Million US\$) }\end{array}$ & $\begin{array}{c}\text { GDP } \\
\text { (Million US\$) }\end{array}$ & $\begin{array}{l}\text { Gross capital } \\
\text { formation } \\
\text { (Million US\$) }\end{array}$ & $\begin{array}{c}\text { Gross } \\
\text { Domestic savings } \\
\text { (Million US\$) }\end{array}$ & $\begin{array}{c}\text { Household final } \\
\text { consumption expenditure } \\
\text { (Million US\$) }\end{array}$ \\
\hline 1995 & 119 & 52 & 1198 & 52934 & 7254 & 4795 & 31203 \\
\hline 1996 & 121 & 52 & 1217 & 55328 & 9627 & 6532 & 36618 \\
\hline 1997 & 124 & 54 & 1475 & 57812 & 10525 & 7975 & 37610 \\
\hline 1998 & 126 & 55 & 1525 & 60805 & 11057 & 8875 & 38108 \\
\hline 1999 & 129 & 57 & 1706 & 63645 & 11649 & 9152 & 39085 \\
\hline 2000 & 132 & 58 & 1949 & 67013 & 12707 & 10234 & 40032 \\
\hline 2001 & 134 & 59 & 1882 & 70416 & 13052 & 10177 & 40236 \\
\hline 2002 & 137 & 60 & 2501 & 73115 & 13321 & 11051 & 40572 \\
\hline 2003 & 139 & 61 & 3062 & 76580 & 14847 & 11962 & 44930 \\
\hline 2004 & 141 & 62 & 3372 & 80593 & 16272 & 13299 & 47944 \\
\hline 2005 & 143 & 62 & 3848 & 85860 & 17937 & 14041 & 51224 \\
\hline 2006 & 145 & 63 & 4802 & 91589 & 18776 & 14895 & 52516 \\
\hline 2007 & 147 & 63 & 5998 & 98054 & 20841 & 16103 & 58828 \\
\hline 2008 & 149 & 64 & 7915 & 103951 & 24009 & 17317 & 69303 \\
\hline 2009 & 150 & 64 & 9689 & 109195 & 26855 & 20489 & 76422 \\
\hline 2010 & 152 & 64 & 10987 & 115279 & 30257 & 23623 & 85439 \\
\hline 2011 & 154 & 66 & 11650 & 122731 & 35274 & 25527 & 95553 \\
\hline 2012 & 156 & 67 & 12843 & 130735 & 37689 & 27304 & 98332 \\
\hline 2013 & 158 & 68 & 14461 & 138597 & 42582 & 31751 & 109265 \\
\hline 2014 & 159 & 69 & 14228 & 146997 & 49407 & 38109 & 125467 \\
\hline 2015 & 161 & 71 & 15317 & 156630 & 56352 & 41891 & 141310 \\
\hline 2016 & 163 & 72 & 14931 & 167771 & 65655 & 55349 & 153064 \\
\hline
\end{tabular}

Source: World Bank (2017a) and Bangladesh Bank (2017) 
How to Cite: Sarkar, M., Rahman, M., Islam, M., Sikdar, M., \& Khan, A. (2018). Relationship between Remittance and Economic Growth: Evidence from Bangladesh. American Journal of Trade and Policy, 5(3), 93-98.

\section{SOCIAL SCIENCE RESEARCH NETWORK 2171 Monroe Avenue, Suite 203, Rochester, NY 14618, USA http://www.ssrn.com/en/} SSRN Link: http://www.ssrn.com/link/American-Journal-Trade-Policy.html 